НАУКОВИЙ ВІСНИК

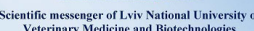

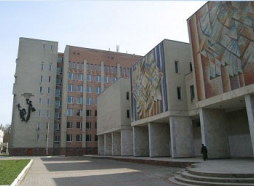

СЕРЯя: ВЕТЕРИНАРНН НАУКИ

Том 22 № 100

2020
Науковий вісник Дьвівського національного університету ветеринарної медицини та біотехнологій імені С.3. Гжицького. Серія: Ветеринарні науки

Scientific Messenger of Lviv National University of Veterinary Medicine and Biotechnologies. Series: Veterinary sciences

UDC 636.598.087.72:611.3:546.34

\title{
Development of digestive organs in goslings raised for meat, depending on lithium level in mixed feeds
}

\author{
M. I. Morklyak ${ }^{1}$, A. A. Grybanova ${ }^{1}$, O. I. Sobolev ${ }^{2}$ \\ ${ }^{1}$ VSP “Tulchyn Vocational College of Veterinary Medicine of Medicine of Bila Tserkva National Agrarian University”, \\ Tulchyn, Ukraine \\ ${ }^{2}$ Bila Tserkva National Agrarian University, Bila Tserkva, Ukraine
}

Article info

Received 19.10.2020

Received in revised form 23.11 .2020

Accepted 24.11.2020

VSP "Tulchyn Vocational College of Veterinary Medicine of Medicine of Bila Tserkva National Agrarian University", Leontovycha Str., 54. Tulchyn, 23600, Ukraine.

Bila Tserkva National Agrarian University, 8/1, Soborna Sq. 09117, Bila Tserkva, Ukraine. Tel.: +38-096-443-91-50 E-mail: soboleva_i@ukr.net
Morklyak, M. I., Grybanova, A. A., \& Sobolev, O. I. (2020). Development of digestive organs in goslings raised for meat, depending on lithium level in mixed feeds. Scientific Messenger of Lviv National University of Veterinary Medicine and Biotechnologies. Series: Veterinary sciences, 22(100), 129-134. doi: $10.32718 /$ nvlvet10022

Recently, the vital necessity of lithium for living organisms has been experimentally proven and also it was previously considered as a conditionally essential trace element. Numerous experimental research conducted on various animals and poultry types have revealed quite wide and diverse properties of lithium, in particular, antimicrobial, antiviral, antitumor, anti-stress and antioxidant. The discovery of biological properties and the disclosure of biochemical mechanisms of lithium action became the basis for its use in veterinary and zootechnical practice. Lithium preparations are successfully used to treat various animal diseases, prevent and correct "technological" stresses in poultry, increase its productive qualities and improve the quality of meat products. Despite the biochemical complexity and practical significance of this trace element, lithium is still insufficiently used during feeding poultry due to the lack of optimal standards for introducing it into mixed feed. During developing optimal standards for lithium introduction into mixed feed, it is necessary to evaluate not only the indicators of poultry productivity and product quality, but also the physiological indicators of its development. The effect of additives of different lithium doses in compound feeds on the development of digestive organs in goslings raised for meat was studied in a scientificeconomic experiment. The research was conducted on the breed of goslings "Danish Legart". The duration of experiment was 70 days. The lithium introduction into compound feeds for goslings, in doses of $0.15 \mathrm{mg} / \mathrm{kg}, 0.20$ and $0.25 \mathrm{mg} / \mathrm{kg}$, had a positive effect on the development of their digestive organs, as evidenced by the tendency to increase the intestine mass (by 2.2-4.8\%) and its total length (by 0.5-1.1\%), as well as an increase in the liver mass (by 2.0-7.0\%) and muscle stomach (by 3.4-7.3\%). Goslings had the best macromorphological indicators of digestive development, whose mixed feed were enriched with lithium at the rate of $0.15 \mathrm{mg} / \mathrm{kg}$ during the entire growing period. A comparison of goslings live weight of the experimental groups with indicators of the development of intestines, liver and muscular stomach allows to claim that their digestive organs were better developed and functioned more actively during the growing period.

Key words: goslings, digestive organs, lithium, dose, mixed feed.

\section{Розвиток органів травлення у гусенят, що вирощуються на м'ясо, залежно від рівня літію у комбікормах}

\author{
М. І. Моркляк ${ }^{1}$, А. А. Грибанова ${ }^{1}$, О. І. Соболєв ${ }^{2}$ \\ ${ }^{1}$ ВСП “Тульчинський фаховий коледж ветеринарної медицини БНАУ”, м. Тульчин, Украӥна \\ ${ }^{2}$ Білочерківський наџіональний аграрний університет, м. Біла Церква, Україна
}


Останнім часом експериментально доведена життєва необхідність для живих організмів літію, який раніше вважсали умовноессенціальним мікроелементом. Чисельні експериментальні дослідження проведені на різних видах тварин і птиці дозволили виявити досить широкі та різнопланові властивості літію, зокрема, антимікробні, антивірусні, протипухлинні, антистресові та антиоксидантні. Відкриття біологічних властивостей та розкриття біохімічних механізмів дї літію стало підставою для використання його у ветеринарній та зоотехнічній практиці. Препарати літію з успіхом використовуються для лікування різних захворювань тварин, профілактики та корекцї “технологічних” стресів у птиці, підвищення ї̈ продуктивних якостей та покрашення якості м'ясної продукиії. Незважаючи на біохімічну багатогранність і практичне значення иього мікроелемента, літій поки що недостатньо використовується у годівлі сільськогосподарської птиці через відсутність оптимальних норм уведення його в комбікорми. При розробці оптимальних норм уведення літію в комбікорми, слід оцінювати не тільки показники продуктивності птиці та якості продукції, а й фізіологічні показники ї̈ розвитку. У науково-господарському досліді вивчено вплив добавок різних доз літію в комбікорми на розвиток органів травлення у гусенят, щзо вирошуються на м'ясо. Дослідження проводилися на гусенятах породи “Датский легарт”. Тривалість досліду становила 70 днів. Введення літію до складу комбікормів для гусенят, у дозах 0,15 мг/кг 0,20 та 0,25 мг/кг позитивно вплинуло на розвиток їх органів травлення, про щео свідчить тенденція до збільшення маси кишечника (на 2,2-4,8 \%) та загальної його довжини (на 0,5-1,1\%), а також підвищення маси печінки (на 2,0-7,0 \%) та м'язового илунка (на 3,4-7,3\%). Кращуі макроморфологічні показники розвитку органів травлення мали гусенята, комбікорми яких упродовж усього періоду вирощування збагачували літієм із розрахунку 0,15 мг/кг. Співставлення живої маси гусенят дослідних груп з показниками розвитку кишечнику, печінки та м'язового шлунка дозволяє стверджувати, щзо органи травлення у них були розвинуті краще та упродовж періоду вирощування функціонували більи активно.

Ключові слова: гусенята, органи травлення, літій, доза, комбікорм.

\section{Вступ}

Птахівництво $\epsilon$ найдинамічнішою та високо ефективною галуззю тваринництва у багатьох країнах світу, яка окрім стабільного забезпечення населення якісними дієтичними продуктами харчування сприяє розвитку технологічно пов'язаних галузей і виробництв та формує основи соціально-економічного розвитку сільських територій.

Проблеми підвищення продуктивності сільськогосподарської птиці, ефективності використання кормів, покращення якості продукції залишаються актуальними і розробляється у різних аспектах. Наукові дослідження, як правило, тісно пов'язуються 3 практичними завданнями, зокрема, з удосконаленням систем годівлі та утримання птиці, технологічних параметрів вирощування, ветеринарно-профілактичних заходів, способів підготовки та транспортування птиці на забій та ін.

Серед численних елементів технологічного процесу, що забезпечують високу життєдіяльність птиці та максимальну реалізацію іiі генетичного потенціалу, важлива роль відводиться повноцінній годівлі, яка передбачає повне задоволення індивідуальної потреби птиці в обмінній енергії, основних поживних і біологічно активних речовинах, у тому числі й мікроелементах.

Діючі деталізовані норми годівлі передбачають обов'язкове введення в комбікорми для різних видів сільськогосподарської птиці тільки семи мікроелементів (Mn, Fe, Zn, Cu, Co, I, Se) (Bratishko et al., 2013). Проте, на думку вчених, перелік мікроелементів, які використовуються у складі комбікормів для різних видів сільськогосподарської птиці, явно недостатній.

Останніми роками проводяться прикладні дослідження щодо визначення фізіологічної потреби птиці у мінеральних елементах, які раніше не враховувалися у раціонах, але, як доведено, справляють позитивний вплив на організм. До таких біоелементів, що, на думку вчених, підлягають обов'язковому нормуванню, належить і літій (Bachinskaja \& Preobrazhenskij, 2009). За класифікацією, що грунтується на біологічній ролі для живих організмів та широко використовується у біохімії та фізіології, літій відноситься до групи умовно-есенціальних елементів (Prashanth et al., 2015). Проте, сьогодні він розглядається вченими як “серйозний кандидат на есенціальність” (Bauer \& Gitlin, 2016; Sobolev et al., 2019).

Чисельні експериментальні дослідження проведені на різних видах тварин і птиці дозволили виявити досить широкі та різнопланові властивості літію. Він володіє антимікробними (Stachelska, 2015), антивірусними (Qian et. al., 2018), протипухлинними (Wu et al., 2013), антиметастатичними (Maeng et al., 2016), антистресовими (Galochkin et al., 2018), радіозахисними (Tarumov \& Antushevich, 2013), імуномодулюючими (Lohitha \& Singh, 2019) та антиоксидантними (Plotnikov et al., 2016) властивостями. Існують прямі клінічні докази впливу літію на остеогенез (Wang et al., 2015).

Відкриття біологічних властивостей та розкриття біохімічних механізмів дії літію стало підставою для використання його у ветеринарній та зоотехнічній практиці. У ветеринарії препарати літію 3 успіхом використовуються для лікування різних захворювань тварин, зокрема, циклічного гемопоезу (Bach \& Gallicchio, 1990), тромбоцитопенії (Leclerc et al., 2010), мієлосупресії (Abrams-Ogg, 2011) та естрогеніндукованої мієлотоксичності у собак (Sontas et al., 2009).

У зоотехнії, зокрема птахівництві, літій стали використовувати порівняно недавно. Різні препарати літію використовують 3 метою профілактики та корекції “технологічних” стресів при пересадці та транспортуванні молодняку птиці (Abdullaev, 2015), при проведенні дебікування (Anosov \& Miftahutdinov, 2015) та вакцинації курчат (Lukichjova, 2008). Солі літію неорганічних і органічних кислот вводять до складу комбікормів для різних видів сільськогосподарської птиці з метою підвищення їх живої маси, життєздатності та конверсії корму (Bachinskaja, 2009; Grybanova \& Soboljev, 2015), підвищення забійних i м’ясних якостей птиці (Grybanova \& Soboljev, 2013), покращення органолептичних показників м'яса (Lukichjova, 2011), його амінокислотного складу та 
біологічної цінності (Borovkov et al., 2010). Водними розчинами літію різних концентрацій проводять передінкубаційну аерозольну обробку куриних яєць 3 метою підвищення їх виводимості та виводу молодняку (Belousova et al., 2011).

Оскільки з'ясувалося, що літій активує дію багатьох ферментів та гормонів і тим самим забезпечує їхню фізіологічну функцію, то деякі вчені останнім часом пов'язують підвищення продуктивних якостей птиці зі зміною інтенсивності обміну речовин в організмі. На сьогодні доведено, що під впливом літію покращується перетравність поживних речовин корму та підвищується відкладання нітрогену в організм птиці (Sobolev et al., 2019).

Як видно з викладеного вище, вже перші спроби використання літію у зоотехнічній практиці дозволили одержати результати, які доводять безумовну необхідність визначення оптимальних диференційованих норм уведення його в комбікорми для сільськогосподарської птиці різного виду, віку і напряму продуктивності.

При розробці та теоретичному обгрунтуванні оптимальних норм уведення літію в комбікорми, слід оцінювати не тільки показники продуктивності птиці та якості продукції, а й фізіологічні показники іiї розвитку. Відомо, що ріст молодняку птиці нерозривно пов'язаний з розвитком органів травлення, де з'їений корм перетворюється у речовини, придатні для асиміляції в організмі. Розуміння закономірностей розвитку i будови органів травлення сільськогосподарської птиці $є$ біологічною основою розробки системи повноцінного живлення.

Аналіз доступних наукових публікацій дав змогу дійти висновку, що до цього часу відсутні експериментальні дані щодо впливу добавок літію в комбікорми на розвиток системи органів травлення у сільськогосподарської птиці, у тому числі й молодняку гусей.

У зв'язку з цим, метою наших досліджень було вивчення впливу різних рівнів літію в комбікормах на розвиток органів травлення у гусенят, що вирощуються на м'ясо.

\section{Матеріал і методи досліджень}

Дослідження проводилися на гусенятах породи “Датский легарт”. Для проведення науковогосподарського досліду формували групи із добового молодняку за принципом аналогів 3 урахуванням походження, живої маси та фізіологічного стану (Fisinin, 2013). Тривалість досліду відповідала періоду вирощування гусенят на м'ясо і становила 70 днів.

Годівлю піддослідного молодняку протягом періоду вирощування здійснювали сухими повнораціонними комбікормами, що збалансовані за основними поживними та біологічно активними речовинами, відповідно до існуючих норм. Гусенята першої контрольної групи добавку літію у комбікорми не одержували. Птиці дослідних груп у комбікорми додатково вводили різну кількість літію, мг/кг: друга група 0,15; третя - 0,20 та четверта - 0,25. Як джерело літію, використовували його наноаквахелатну форму.

Молодняк гусей вирощували на глибокій підстилці, за вільного доступу до корму і води, з дотриманням технологічних параметрів щільності посадки, мікроклімату та освітлення відповідно до існуючих норм (Galibarenko et al., 2005).

По закінченні науково-господарського досліду було відібрано по 3 голови птиці з кожної групи і проведено їх контрольний забій відповідно до загальноприйнятої методики. При відборі гусенят для контрольного забою середня жива маса їх відповідала середній масі птиці по даній групі в кінці періоду вирощування. Після контрольного забою гусенят проводили ïх повне анатомічне розбирання згідно з існуючими рекомендаціями (Lukashenko, 2013).

При математичному опрацюванні результатів досліджень використовували комп'ютерні програми статистичної обробки Microsoft Excel. Різницю між групами оцінювали за критерієм Стьюдента і вважали вірогідною при значені - $\mathrm{P}<0,05$.

\section{Результати та їх обговорення}

Аналіз результатів науково-господарського досліду і вивчення розвитку органів травлення у гусенят виявив деякі відмінності між групами, які, на нашу думку, обумовлені опосередкованою дією різних доз літію (табл. 1).

Встановлено, що молодняк усіх дослідних груп перевищував за живою масою на кінець вирощування своїх ровесників 3 контрольної групи. Найвищим цей показник виявився у гусенят другої дослідної групи 4490,3 г. Різниця порівняно 3 контрольною групою становила 2,2\% і була статистично вірогідною $(\mathrm{P}<0,05)$.

Більш високі дози введення літію $(0,20$ та 0,25 мг/кг) у комбікорми, обумовили менш інтенсивний ріст і нижчу живу масу гусенят інших дослідних груп, порівняно 3 молодняком другої групи, якому згодовували комбікорми 3 добавкою літію 0,15 мг/кг. Проте, середня жива маса птиці третьої дослідної групи була вищою, ніж у їх ровесників із контрольної групи на $1,9 \%$ (P < 0,05), четвертої - на $1,5 \%$ і становила 4478,0 та 4459,7 г відповідно.

Результати проведених вимірювань показали, що у птиці дослідних груп спостерігалася тенденція до збільшення загальної довжини кишечника. Найбільшою абсолютна довжина кишечника виявилася у гусенят другої дослідної групи (308,5 см). Порівняно 3 контрольною групою різниця становила 1,1%. Молодняк третьої та четвертої дослідних груп за цим показником дещо поступався своїм ровесникам $з$ другої дослідної групи, проте, він перевищував контрольних на 0,8 та $0,5 \%$ відповідно. 


\section{Таблищя 1}

Макроморфологічні показники органів травлення гусенят, $\bar{X} \pm S_{\bar{X}}$

\begin{tabular}{lcccc}
\hline \multicolumn{1}{c}{ Показник } & \multicolumn{3}{c}{ Група } \\
\cline { 2 - 5 } & 1 контрольна & 2 дослідна & 3 дослідна & 4 дослідна \\
\hline Передзабійна жива маса, г & $4393,7 \pm 20,86$ & $4490,3 \pm 21,52^{*}$ & $4478,0 \pm 17,68^{*}$ & $4459,7 \pm 19,82$ \\
Абсолютна довжина кишечника, см & $305,0 \pm 6,16$ & $308,5 \pm 5,49$ & $307,3 \pm 2,48$ & $306,5 \pm 3,72$ \\
у т.ч. тонкого відділу & $237,5 \pm 6,55$ & $243,2 \pm 7,11$ & $242,7 \pm 5,12$ & $240,4 \pm 0,61$ \\
$\quad$ товстого відділу & $67,5 \pm 2,32$ & $65,3 \pm 2,01$ & $64,6 \pm 3,19$ & $66,0 \pm 3,24$ \\
Маса кишечника, г & $198,7 \pm 17,47$ & $208,3 \pm 10,64$ & $206,0 \pm 7,97$ & $203,0 \pm 5,34$ \\
\% до живої маси & 4,5 & 4,6 & 4,6 & 4,6 \\
Маса печінки, г & $76,0 \pm 1,41$ & $81,3 \pm 21,63$ & $79,3 \pm 1,81$ & $77,5 \pm 2,55$ \\
\% до живої маси & 1,7 & 1,8 & 1,8 & 1,7 \\
Маса м'язового шлунку, г & $180,5 \pm 2,67$ & $193,7 \pm 2,16^{*}$ & $192,0 \pm 1,87^{*}$ & $186,7 \pm 2,86$ \\
\% до живої маси & 4,1 & 4,3 & 4,3 & 4,2 \\
\hline Примітка: вірогідність різниці між контрольною та дослідними групами - ${ }^{*} \mathrm{P}<0,05$ & \multicolumn{2}{c}{}
\end{tabular}

Слід відзначити, що збільшення абсолютної довжини кишечника у птиці дослідних груп відбулося за рахунок збільшення лінійних розмірів тонкого відділу, до складу якого входять дванадцятипала, порожня та клубова кишки. Так, довжина тонкого відділу кишечника у гусенят другої дослідної групи підвищилася на 5,7 см, третьої - на 5,2 та четвертої - на 2,9 см, порівняно 3 аналогічним показником у контрольній групі (237,5 см). Різниця між контрольною та дослідними групами за цим показником була дещо вищою, ніж за показником абсолютної довжини кишечника, i становила 1,2-2,4 \% на користь останніх

Даний факт, на наш погляд, є важливим, тому що саме в тонкому відділі кишечнику птиці відбуваються основні процеси гідролітичного і бактеріального розщеплення поживних речовин корму та засвоєння утворених речовин. Просуваючись по тонкому відділу кишечнику, хімус змішується із кишковим соком та соком підшлункової залози, зокрема жовчними кислотами і панкреатичною ліпазою, які сприяють подальшому розщепленню основних поживних речовин корму. У результаті збільшення довжини тонкого відділу кишечника у птиці збільшується час проходження кормових мас по ньому і, як наслідок, збільшується час дії протеолітичних ензимів на хімус. А відтак - підвищується перетравність і засвоюваність поживних речовин корму в організмі птиці. Це певною мірою пояснює вищі показники живої маси у гусенят дослідних груп.

Відмінності між групами за розмірами товстого відділу кишечника, до складу якого входять сліпі та пряма кишки, виявилися незначними і не мали певного закономірного зв'язку, як з його загальною довжиною, так і з рівнем літію в комбікормах. Так, довжина товстого відділу кишечника у гусенят другої, третьої та четвертої дослідних груп була на 2,2 см, 2,9 та 1,5 см відповідно менше, ніж у молодняку з контрольної групи (67,5 см).

Привертає увагу і той факт, що у птиці всіх дослідних груп збільшилася на 2,2-4,8 \% абсолютна та на 0,1 \% відносна маса кишечника, порівняно з контрольною групою, де аналогічні показники становили 198,7 г та 4,5 \% відповідно.

Беручи до уваги фізіологічну роль найбільшої екзокринної залози - печінки та жовчі, яку вона вироб- ляє, у процесах травлення, обміні білків, жирів, вуглеводів, ферментів та вітамінів; водному, мінеральному та пігментному обмінах; знешкодженні ряду ендогенних токсичних продуктів клітинного метаболізму та речовин, що надійшли ззовні, ми дослідили їі розвиток у піддослідної птиці. Слід зазначити, що у гусенят дослідних груп спостерігалася тенденція до підвищення абсолютної маси печінки. Так, різниця між контрольною та дослідними групами, на користь останніх, становила: у другій $-7,0 \%$, у третій $-4,3$ та четвертій - 2,0\%. Відносна маси печінки також збільшилася на $0,1 \%$, але лише у гусенят другої та третьої дослідних груп. У четвертій дослідній групі, цей показник знаходився на рівні контрольного варіанту.

Згодовування гусенятам упродовж періоду вирощування комбікормів, збагачених різними дозами літію, позитивно вплинуло на формування і розвиток у них м'язового шлунка (186,7-193,7 г проти 180,5 г у контрольній групі). Найбільша абсолютна маса м'язового шлунка виявилася у молодняку другої дослідної та третьої дослідних груп. Різниця, порівняно 3 контрольною групою, становила відповідно 7,3 та $6,4 \%$ і була статистично вірогідною $(\mathrm{P}<0,05)$. Різниця за цим показником у птиці четвертої дослідної групи була дещо нижчою - 3,4 \% і статистично невірогідною. Відносна маса м'язового шлунка у гусенят дослідних груп, порівняно 3 аналогічним показником у контрольній групі, також підвищилася на 0,1-0,2%.

\section{Висновки}

Введення літію до складу комбікормів для гусенят, у дозах, які вивчалися, позитивно вплинуло на розвиток їх органів травлення, про що свідчить тенденція до збільшення маси та абсолютної довжини кишечника у цілому і його тонкого відділу зокрема, а також підвищення маси печінки та м'язового шлунка. Кращі макроморфологічні показники розвитку органів травлення мали гусенята, комбікорми яких упродовж усього періоду вирощування збагачували літієм із розрахунку 0,15 мг/кг. Співставлення живої маси гусенят дослідних груп з показниками розвитку кишечника, печінки та м'язового шлунка дозволяє стверджувати, що органи травлення у них були розвинуті 
краще та упродовж періоду вирощування функціонували більш активно.

\section{References}

Abdullaev, I. (2015). Izuchenie vlijanija litija karbonata, kak antistressovogo preparata pri peresadke i transportirovke molodnjaka kur. Agrarnaja tema, 11, 32-33 (in Russian).

Abrams-Ogg, A. C. G. (2011). The use of lithium carbonate to prevent lomustine-induced myelosuppression in dogs: a pilot study. Canadian journal of veterinary research. Revue canadienne de recherche veterinaire, 75(1), 73-76. URL: https://www.ncbi.nlm.nih.gov/pmc/articles/PMC3003 567.

Anosov, D. E. \& Miftahutdinov, A. V. (2015). Sravnitel'noe vozdejstvie litijsoderzhashhih farmakologicheskih sredstv na sostojanie prooksidantnoj i antioksidantnoj sistem organizma cypljat pri debikirovanii. APK Rossii, 73, 145-150 (in Russian).

Bach, R. O., \& Gallicchio, V. S. (1990). Lithium and Cell Physiology. Springer-Verlag. doi: 10.1007/978-14612-3324-4.

Bachinskaja, V. M. (2009). Veterinarno-sanitarnaja jekspertiza mjasa brojlerov pri podkormke litiem karbonata. Veterinarnaja medicina, 1-2, 21-22 (in Russian)

Bachinskaja, V. M., \& Preobrazhenskij, S. N. (2009). Izuchenie ostroj toksichnosti litija karbonata dlja brojlerov i krys. Veterinarnaja medicina, 3, 32-34 (in Russian).

Bauer, M., \& Gitlin, M. (2016). Lithium and its history. In: The essential guide to lithium treatment. Springer, Cham, 25-31. doi: 10.1007/978-3-319-31214-9_3.

Belousova, R. V., Lukicheva, V. A., \& Ermolaev, A. S. (2011). Vlijanie preparata litija glicinata na vyvod $i$ vyvodimost' cypljat-brojlerov. Zootehnija, 8, 26 (in Russian).

Borovkov, M. F., Kalashnikova, A. V., \& Bachinskaja, V. M. (2010). Aminokislotnyj sostav tushek brojlerov pri primenenii litija karbonata. Veterinarnaja medicina, 1, 18-19 (in Russian).

Bratishko, N. I., Ionov, I. A., Ibatullin, I. I., Prytulenko, O. V., Klymenko, T. Je., Kotyk, A. M., Katerynych, O. O., Zhukors'kyj, O. M., Gavilej, O. V., Poljakova, L. L., \& Grycenko R. B. (2013). Efektyvna godivlja sil's'kogospodars'koi' ptyci. Agrarna nauka. Kyi'v (in Ukrainian).

Fisinin, V. I. (2013). Metodika provedenija nauchnyh i proizvodstvennyh issledovanij po kormleniju sel'skohozjajstvennoj pticy: rekomendacii. VNIITIP, Sergiev Posad (in Russian).

Galochkin, V. A., Ostrenko, K. S. \& Galochkina, V. P. (2018). Primenenie novogo antistressovogo preparata (askorbat litija) dlja povyshenija produktivnosti cypljat-brojlerov. Problemy biologii produktivnyh zhivotnyh, 2, 68-80 (in Russian).

Galibarenko, M., Smirnov, O., Pasichnyi, V., Riabokon, Yu., Ivko, I., Melnyk, B., Pudov, V., Kulbaba, C.,
Duiunov, B., Sokhatskyi, M., Vashkulat, M., Kyreieva, I., Bulyha, N., \& Demydenko, V. (2005). VNTP-APK-04. 05. Pidpryiemstva ptakhivnytstva. Ministerstvo ahrarnoi polityky. Kyiv (in Ukrainian).

Grybanova, A. A., \& Sobolev, O. I. (2013). M'jasna produktyvnist' gusenjat za vykorystannja u kombikormah dobavok litiju. Tehnologija vyrobnyctva i pererobky produkcii' tvarynnyctva, 10, 34-37 (in Ukrainian).

Grybanova, A. A. \& Sobolev, O. I. (2015). Produktyvni jakosti gusenjat, shho vyroshhujut'sja na m'jaso za vykorystannja u kombikormah dobavok Litiju. Tehnologija vyrobnyctva i pererobky produkcii' tvarynnyctva, 1, 145-149 (in Ukrainian).

Leclerc, A., Abrams-Ogg, A. C., Kruth, S. A. \& Bienzle, D. (2010). Effects of lithium carbonate on carboplatininduced thrombocytopenia in dogs. American journal of veterinary research, 17(5), 555-563. doi: 10.2460/ajvr.71.5.555.

Lohitha G. \& Singh, P. P. (2019). Lithium: immunomodulatory and anti-infectious. Activities Journal of Pharmaceutical Research, 4(1), 1-11. doi: 10.33140/jpr.04.01.06.

Lukashenko, V. S. (2013). Metodika provedenija anatomicheskoj razdelki tushek, organolepticheskoj ocenki kachestva mjasa i jaic sel'skohozjajstvennoj pticy i morfologii jaic: metodicheskoe rukovodstvo. VNIITIP. Sergiev Posad (in Russian).

Lukichjova, V. (2008). Profilaktika vakcional'nogo stressa. Pticevodstvo, 12, 21 (in Russian).

Lukichjova, V. (2011). Soli litija v racione pitanija pticy uluchshajut kachestvo mjasnoj produkcii. Agrarnoe obozrenie, 5(27), 54-55 (in Russian).

Maeng, Y. S., Lee, R., Lee, B., Choi, S. I., \& Kim, E. K. (2016). Lithium inhibits tumor lymphangiogenesis and metastasis through the inhibition of TGFBIp expression in cancer cells. Scientific Reports, 6, 20739. doi: 10.1038/srep20739.

Plotnikov, E., Voronova, O., Linert, W., Martemianov, D., Korotkova, E., Dorozhko, E., Astashkina, A., Martemianova, I., Ivanova, S., \& Bokhan, N. (2016). Antioxidant and immunotropic properties of some lithium salts. Journal of Applied Pharmaceutical Science, 6(1), 86-89. doi: 10.7324/JAPS.2016.600115.

Poljanskaja, I. S. (2014). Novaja klassifikacija biojelementov $\mathrm{v}$ biojelementologii. Molochnohozjajstvennyj vestnik, 1(13), 34- 42 (in Russian).

Prashanth, L., Kattapagari, K. K., Chitturi, R. T., Baddam, V. R., \& Prasad, L. K. (2015). A review on role of essential trace elements in health and disease. Journal Dr.NTR University of Health Sciences, 4(2), 75-85. doi: $10.4103 / 2348-2915.133959$.

Qian, K., Cheng, X., Zhang, D., Shao, H., Yao, Y., Nair, V. \& Qin, A. (2018). Antiviral effect of lithium chloride on replication of avian leukosis virus subgroup $\mathrm{J}$ in cell culture. Archives of Virology, 163(4), 987-995. doi: 10.1007/s00705-017-3692-7.

Sobolev, O. I., Gutyj, B. V., Darmohray, L. M., Sobolieva, S. V., Ivanina, V. V., Kuzmenko, O. A., Karkach, P. M., Fesenko, V. F., Bilkevych, V. V., Mashkin, Y. O., Trofymchuk, A. M., Stavetska, R. V., 
Tkachenko, S. V., Babenko, O. I., Klopenko, N. I., \& Chernyuk, S. V. (2019). Lithium in the natural environment and its migration in the trophic chain. Ukrainian Journal of Ecology, 9(2), 195-203. URL: https://www.ujecology.com/abstract/lithium-in-thenatural-environment-and-its-migration-in-the-trophicchain-43899.html.

Sobolev, O. I., Gutyj, B. V., Sobolieva, S. V., Fesenko, V. F., Bilkevych, V. V., Babenko, O. I., Klopenko, N. I., Kachan, A. D., Kosior, L. T., Lastovska, I. O., Vered, P. I., Shulko, O. P., Onyshchenko, L. S., \& Slobodeniuk, O. I. (2019). The influence of different doses of lithium additive in mixed feed on the balance of nitrogen in organism of goslings. Ukrainian Journal of Ecology, 9(2), 91-96. URL: https://www.ujecology.com/abstract/the-influence-ofdifferent-doses-of-lithium-additive-in-mixed-feed-onthe-balance-of-nitrogen-in-organism-of-goslings25912.html.

Sobolev, O. I., Gutyj, B. V., Sobolieva, S. V., Shaposhnik, V. M., Sljusarenko, A. A., Stoyanovskyy, V. G., Kamratska, O. I., Karkach, P. M., Bilkevych, V. V., Stavetska, R. V., Babenko, O. I., Bushtruk, M. V., Starostenko, I. S., Klopenko, N. I., Korol'-Bezpala, L. P. \& Bezpalyi, I. F. (2019). Digestibility of nutrients by young geese for use of lithium in the composition of fodder. Ukrainian Journal of Ecology, 9(1), 1-6. URL: https:/www.ujecology.com/abstract/digestibility-of- nutrients-by-young-geese-for-use-of-lithium-in-thecomposition-of-fodder-18131.html.

Sontas, H. B., Dokuzeylu, B., Turna, O. \& Ekici, H. (2009). Estrogen-induced myelotoxicity in dogs: a review. The Canadian veterinary journal $=$ La revue veterinaire canadienne, 50(10), 1054-1058. URL: https://www.ncbi.nlm.nih.gov/pmc/articles/PMC2748 286.

Stachelska, M. A. (2015). Inhibitory properties of lithium, sodium and potassium $\mathrm{o}-, \mathrm{m}^{-}$and $\mathrm{p}$-coumarates against Escherichia coli O157:H7. Acta scientiarum polonorum. Technologia alimentaria, 14(1), 77-84. doi: 10.17306/J.AFS.2015.1.9.

Tarumov, R. A., \& Antushevich, A. A. (2013). Vlijanie antioksidanta litana na dinamiku gematologicheskih pokazatelej u obluchennyh krys. Vestnik novyh medicinskih tehnologij, 20(2), 223-226 (in Russian).

Wang, X., Zhu, S., Jiang, X., Li, Y., Song, D., \& Hu, J. (2015). Systemic administration of lithium improves distracted bone regeneration in rats. Calcified Tissue Research, 96(6), 534-540. doi: 10.1007/s00223-0150004-7.

Wu, S., Zheng, S. D., Huang, H. L., Yan, L. C., Yin, X. F., Xu, H. N., Zhang, K. J., Gui, J. H., Chu, L., \& Liu, X. Y. (2013). Lithium down-regulates histone deacetylase 1 (HDAC1) and induces degradation of mutant huntingtin. The Journal of biological chemistry, 288(49), 35500-35510. doi: 10.1074/jbc.M113.479865. 